\title{
$\alpha$-Synuclein Mutation Inhibits Endocytosis at Mammalian Central Nerve Terminals
}

\author{
다ianhua Xu, ${ }^{1 \star}$ Xin-Sheng Wu, ${ }^{2 \star}$ Jiansong Sheng, ${ }^{2}$ Zhen Zhang, ${ }^{2}$ Hai-Yuan Yue, ${ }^{1}$ Lixin Sun, ${ }^{3}$ Carmelo Sgobio, ${ }^{3}$ \\ Xian Lin, ${ }^{3}$ Shiyong Peng, ${ }^{2}$ Yinghui Jin, ${ }^{2}$ Lin Gan, ${ }^{4}$ Huaibin Cai, ${ }^{3}$ and Ling-Gang Wu ${ }^{2}$ \\ ${ }^{1}$ Department of Neuroscience and Regenerative Medicine, Medical College of Georgia, Augusta, Georgia 30912, ${ }^{2}$ National Institute of Neurological \\ Disorders and Stroke, National Institutes of Health, Bethesda, Maryland 20892, ${ }^{3}$ National Institute on Aging, National Institutes of Health, Bethesda, \\ Maryland 20892, and ${ }^{4}$ Flaum Eye Institute, University of Rochester School of Medicine and Dentistry, Rochester, New York 14642
}

$\alpha$-Synuclein ( $\alpha$-syn) missense and multiplication mutations have been suggested to cause neurodegenerative diseases, including Parkinson's disease (PD) and dementia with Lewy bodies. Before causing the progressive neuronal loss, $\alpha$-syn mutations impair exocytosis, which may contribute to eventual neurodegeneration. To understand how $\alpha$-syn mutations impair exocytosis, we developed a mouse model that selectively expressed PD-related human $\alpha$-syn A53T (h- $\alpha$-syn $\left.{ }_{\mathrm{A} 53 \mathrm{~T}}\right)$ mutation at the calyx of Held terminals, where release mechanisms can be dissected with a patch-clamping technique. With capacitance measurement of endocytosis, we reported that h- $\alpha$ $\operatorname{syn}_{\mathrm{A} 53 \mathrm{~T}}$, either expressed transgenically or dialyzed in the short term in calyces, inhibited two of the most common forms of endocytosis, the slow and rapid vesicle endocytosis at mammalian central synapses. The expression of h- $\alpha$-syn ${ }_{\mathrm{A} 53 \mathrm{~T}}$ in calyces also inhibited vesicle replenishment to the readily releasable pool. These findings may help to understand how $\alpha$-syn mutations impair neurotransmission before neurodegeneration.

Key words: $\alpha$-synuclein; endocytosis; nerve terminal; Parkinson's disease; transmitter; vesicle

\section{Significance Statement}

$\alpha$-Synuclein ( $\alpha$-syn) missense or multiplication mutations may cause neurodegenerative diseases, such as Parkinson's disease and dementia with Lewy bodies. The initial impact of $\alpha$-syn mutations before neuronal loss is impairment of exocytosis, which may contribute to eventual neurodegeneration. The mechanism underlying impairment of exocytosis is poorly understood. Here we report that an $\alpha$-syn mutant, the human $\alpha$-syn A53T, inhibited two of the most commonly observed forms of endocytosis, slow and rapid endocytosis, at a mammalian central synapse. We also found that $\alpha$-syn A53T inhibited vesicle replenishment to the readily releasable pool. These results may contribute to accounting for the widely observed early synaptic impairment caused by $\alpha$-syn mutations in the progression toward neurodegeneration.

\section{Introduction}

Mutations of $\alpha$-synuclein ( $\alpha$-syn), such as A53T, A30P, E46K, H50Q, G51D, and A53E missense mutations, and multiplication mutations have been suggested to cause neurodegenerative dis-

\footnotetext{
Received Sept. 30, 2015; revised Jan. 29, 2016; accepted Feb. 26, 2016.

Author contributions: J.X., J.S., L.S., H.C., and L.-G.W. designed research; J.X., X.-S.W., J.S., Z.Z., H.-Y.Y., L.S., C.S., X.L., S.P., Y.J., and L.G. performed research; L.G. and H.C. contributed unpublished reagents/analytic tools; J.X., J.S., L.S., and L.-G.W. analyzed data; J.X., H.C., and L.-G.W. wrote the paper.

This work was supported by the intramural research programs of the National Institute of Neurological Disorders and the National Institute on Aging (Grants AG-000929 and AG-000928, to H.C.), and the extramural program of National Institutes of Health (Grant 1R01-NS-082759).

*J.X. and X.-S.W. contributed equally to this study.

The authors declare no conflict of interest.

Correspondence should be addressed to either of the following: Jianhua Xu, Department of Neuroscience and Regenerative Medicine, Medical College of Georgia, Augusta, GA 30912, E-mail: jxu1@gru.edu; or Huaibin Cai, National Institute on Aging, National Institutes of Health, Bethesda, MD 20892, E-mail: caih@mail.nih.gov. DOI:10.1523/JNEUROSCI.3627-15.2016

Copyright $\odot 2016$ the authors $\quad 0270-6474 / 16 / 364408-07 \$ 15.00 / 0$
}

eases, such as Parkinson's disease (PD) and dementia with Lewy bodies (Petrucci et al., 2016). Before causing the progressive neuronal loss, $\alpha$-syn mutations suppress the release of neurotransmitters and hormones at synapses and neuroendocrine cells (Kurz et al., 2010; Nemani et al., 2010; Scott et al., 2010; Lundblad et al., 2012; Janezic et al., 2013). Impairment of exocytosis represents the earliest defects in the progression toward PD (Nemani et al., 2010; Bendor et al., 2013), which may contribute to eventual neurodegeneration. However, how $\alpha$-syn mutations impair exocytosis remains poorly understood.

At cultured hippocampal synapses, $\alpha$-syn mutations reduce the recycling vesicle pool, which is attributed to impairment of vesicle reclustering after endocytosis (Nemani et al., 2010). However, direct evidence showing that vesicle reclustering controls exocytosis is still needed to prove this hypothesis. Although $\alpha$-syn overexpression has been implicated to inhibit vesicle priming in PC12 and chromaffin cells (Larsen et al., 2006), whether this 
mechanism applies to neurons is unclear. Injection of mutant or wild-type $\alpha$-syn into lamprey nerve terminals reduces the number of synaptic vesicles and expands terminal membrane, implying that elevated $\alpha$-syn impairs vesicle endocytosis (Busch et al., 2014). However, direct evidence showing inhibition of the endocytosis time course is missing, and whether the results apply to mammalian central synapses is unclear.

The difficulty in studying presynaptic mechanisms is often due to limited tools in small nerve terminals. Here, we developed a mouse model with human $\alpha$-syn A53T (h- $\alpha$-syn A53T $_{\text {) }}$ expressed specifically in the large calyx of Held nerve terminal that can be patch clamped (Borst and Soria van Hoeve, 2012). We found that $\mathrm{h}-\alpha$-syn $\mathrm{A}_{\mathrm{A} 3 \mathrm{~T}}$ overexpression or short-term elevation inhibited two of the most commonly observed forms of endocytosis, slow and rapid endocytosis. The expression of $\mathrm{h}-\alpha$-syn $\mathrm{A}_{\mathrm{A} 5 \mathrm{~T}}$ also inhibited vesicle replenishment to the readily releasable pool (RRP). These results may help to understand the mechanisms underlying the early impairment of transmitter release caused by $\alpha$-syn mutations.

\section{Materials and Methods}

Animals. Animal care and use were performed following procedures approved by the Animal Care and Use Committees of the National Institutes of Health and the Medical College of Georgia. Math5 Cre/Cre knock-in mice generated previously (Yang et al., 2003) were kept as homozygous. ROSA:LNL:tTA transgenic mice (Wang et al., 2008) were purchased from The Jackson Laboratory. tetO-A53T mice, which express $\mathrm{h}-\alpha-\operatorname{syn}_{\mathrm{A} 53 \mathrm{~T}}$ when tetO is activated by tetracycline transactivator protein (tTA), were generated previously (Lin et al., 2012). We bred Math5 Cre/Cre knock-in mice with ROSA:LNL:tTA transgenic mice to generate ROSA: LNL:tTA/Math $5{ }^{\text {Cre }}$ mice, in which tTA is turned on specifically at calyces. We then bred ROSA:LNL:tTA/Math $5{ }^{\text {Cre }}$ mice with tetO-A53T mice to generate tetO-A53T/ROSA:LNL:tTA/Math5 ${ }^{\text {Cre }}$ (h- $\alpha$-syn ${ }_{\text {A53T calyx }}$ ) mice, in which tTA activates tetO to express $\mathrm{h}-\alpha-\operatorname{syn}_{\mathrm{A} 53 \mathrm{~T}}$ at calyces. Mouse genotypes were determined by PCR with primers described previously (Yang et al., 2003; Wang et al., 2008; Lin et al., 2012).

Slice preparation and capacitance recordings. Parasagittal brainstem slices (200 $\mu \mathrm{m}$ thick) containing the medial nucleus of the trapezoid body were prepared from 7- to 10-d-old male or female mice or Wistar rats using a vibratome (Wu et al., 2009). Calyces were randomly selected for whole-cell patch-clamp capacitance measurements using the EPC-9 amplifier and the software lock-in amplifier (Wu et al., 2009). The sinusoidal stimulus frequency was $1 \mathrm{kHz}$, and the peak-to-peak voltage was $60 \mathrm{mV}$.

We pharmacologically isolated presynaptic $\mathrm{Ca}^{2+}$ currents with a bath solution $\left(22-24^{\circ} \mathrm{C}\right)$ containing the following (in mM): $105 \mathrm{NaCl}, 20 \mathrm{TEA}-$ $\mathrm{Cl}, 2.5 \mathrm{KCl}, 1 \mathrm{MgCl}_{2}, 2 \mathrm{CaCl}_{2}, 25 \mathrm{NaHCO}_{3}, 1.25 \mathrm{NaH}_{2} \mathrm{PO}_{4}, 25$ glucose, 0.4 ascorbic acid, 3 myo-inositol, 2 sodium pyruvate, 0.001 tetrodotoxin, and 0.1 3,4-diaminopyridine, $\mathrm{pH} 7.4$ when bubbled with $95 \% \mathrm{O}_{2}$ and $5 \%$ $\mathrm{CO}_{2}$. A presynaptic pipette contained the following (in mM): 125 Csgluconate, $20 \mathrm{CsCl}, 4 \mathrm{MgATP}, 10 \mathrm{Na}_{2}$-phosphocreatine, $0.3 \mathrm{GTP}, 10$ HEPES, and 0.05 BAPTA, pH 7.2, adjusted with CsOH. h- $\alpha$-Syn, h- $\alpha-$ $\operatorname{syn}_{\mathrm{A} 53 \mathrm{~T}}$, and $\mathrm{h}-\alpha-\mathrm{syn}_{\mathrm{A} 30 \mathrm{P}}$ were purchased from Sigma-Aldrich in powder form, and were dissolved in pipette solution.

For EPSC recordings, transverse brainstem slices were prepared. EPSCs were induced by an electrical stimulus $(0.2 \mathrm{~ms}, 8-20 \mathrm{~V})$ via a bipolar electrode positioned at the midline of the trapezoid body where presynaptic axon fibers pass through. Pipettes (2-3 M $\Omega$ ) for EPSC recordings contained the following (in mM): $125 \mathrm{~K}$-gluconate, $20 \mathrm{KCl}, 4 \mathrm{MgATP}, 10 \mathrm{Na}_{2}$ phosphocreatine, 0.3 GTP, 10 HEPES, and 0.5 EGTA, pH 7.2, adjusted with $\mathrm{KOH}$. The series resistance $(<15 \mathrm{M} \Omega)$ was compensated by $95 \%$.

Immunohistochemistry and native gel electrophoresis. Postnatal day 9 (P9) mice were anesthetized using Nembutal and transcardially perfused with $4 \%$ paraformaldehyde (Electron Microscopy Sciences). The brain was postfixed in $4 \%$ paraformaldehyde overnight and infiltrated with $30 \%$ sucrose for another $48 \mathrm{~h}$. An OCT (Electron Microscopy Sciences)embedded brain was sectioned using a cryostat (model CM3050S, Leica) at $30 \mu \mathrm{m}$ thickness. Target proteins at calyces were identified using a rabbit antibody against GFP (1:400; Invitrogen), a guinea pig antibody against $\mathrm{vGluT}_{1}$ (1:5000; Millipore), a rabbit antibody against ZsGreen (1:400; Clontech), and a mouse antibody against $\mathrm{h}-\alpha-\operatorname{syn}_{\mathrm{A} 53 \mathrm{~T}}(\operatorname{syn} 211$; 1:500; Santa Cruz Biotechnology) or against both $\mathrm{h}-\alpha-\operatorname{syn}_{\mathrm{A} 53 \mathrm{~T}}$ and mouse $\alpha$-syn (3H2897; 1:500; Santa Cruz Biotechnology). DyLight-488 donkey anti-mouse antibody, DyLight-488 donkey anti-rabbit antibody, and rhodamine-conjugated donkey anti-guinea pig antibody (1:200; Jackson ImmunoResearch Laboratories) were used as secondary antibodies. Images were collected by Zeiss LSM510 confocal microscopy (40×, 1.3 numerical aperture).

For the detection of $\alpha$-syn on native gels, $4 \mu \mathrm{m} \alpha$-syn recombinant proteins and non-denaturing NativeMark molecular mass markers were loaded on a $4-16 \%$ Bis-Tris native PAGE gel (Invitrogen) and run in the running buffer following the protocol of the manufacturer. After gel transferring, the membrane was fixed and then immunoblotted with the antibody to $\alpha$-syn (C20; 1:1000; Santa Cruz Biotechnology). Bands were visualized using the Odyssey infrared imaging system (LI-COR Biosciences).

Data collection and analysis. As in previous studies (Wu et al., 2009), recordings were made within $10 \mathrm{~min}$ after break in, and the capacitance jump $\left(\Delta C_{m}\right)$ was measured at $0.5 \mathrm{~s}$ after depolarization (depol) to avoid artifacts. The initial decay rate ( Rate $_{\text {decay }}$ ) at calyces was measured within $4 \mathrm{~s}$ after $\mathrm{depol}_{20 \mathrm{~ms}}$, and $1.5 \mathrm{~s}$ after $\operatorname{depol}_{20 \mathrm{~ms} \times 10}$. For statistical analysis a $t$ test was used. Data were presented as the mean \pm SEM.

\section{Results}

To express $\mathrm{h}-\alpha-\operatorname{syn}_{\mathrm{A} 53 \mathrm{~T}}$, the first genetic mutation found in familial PD (Polymeropoulos et al., 1997), specifically in mouse calyces, we combined the tet-off expression system (Lin et al., 2012) with Cre-loxP strategy (Fig. 1). The Math5 Cre (Math5 ${ }^{\mathrm{Cre}}$ ) knock-in mouse drives the expression of Cre from embryonic day 12.5 to adult in calyx-containing neurons in the ventral cochlear nucleus (Saul et al., 2008). However, it is unclear whether the Cre is expressed in most calyces that we randomly selected for patching. To quantify Cre expression in calyces, we bred Math5 ${ }^{\text {Cre }}$ mice with the following two Cre reporter mouse lines: (1) mT/ mGFP mice that expressed membrane-targeted tandem dimer Tomato (mT) before Cre-mediated excision and membranetargeted GFP (mGFP) after excision (Muzumdar et al., 2007); and (2) ZsGreen mice that expressed cytosolic ZsGreen after Cre excision. The expression of Math ${ }^{\text {Cre }}$, labeled with an antibody against GFP or ZsGreen in Math $5^{\mathrm{Cre} /+}$; $\mathrm{mT} / \mathrm{mGFP}^{+/-}$mice (Fig. 1A) or Math5 ${ }^{\mathrm{Cre} /+}$; ZsGreen ${ }^{+/-}$mice (data not shown), was restricted to central auditory brainstem. Coimmunostaining with vesicular glutamate transporter $1\left(\right.$ vGluT $\left._{1}\right)$ that labeled calyces showed that mGFP overlapped with vGluT $\mathrm{v}_{1}$ in $86 \pm 3 \%$ calyces (from three Math $5^{\mathrm{Cre} /+} ; \mathrm{mT} / \mathrm{mGFP}^{+/-}$mice), but not postsynaptic neurons (Fig. 1B). Similar overlap between ZsGreen and vGluT ${ }_{1}$ was observed (Fig. $1 C$ ), indicating that Math5 ${ }^{\mathrm{Cre}}$ is expressed in most calyces.

Next, we crossbred Math5 ${ }^{\text {Cre }}$ with ROSA:LNL:tTA transgenic mice (Wang et al., 2008) to generate Math5 Cre/ROSA:LNL:tTA bigenic mice, in which tTA was turned on specifically at calyces (Fig. 1D). We then crossbred Math $5^{\text {Cre }} /$ ROSA:LNL:tTA mice with tetO-A53T mice (expressing h- $\alpha$-syn ${ }_{\mathrm{A} 53 \mathrm{~T}}$ when tetO was activated by tTA; Lin et al., 2012) to generate Math ${ }^{\mathrm{Cre}} /$ tetO-

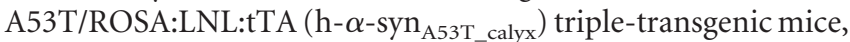
in which tTA activated tetO to express $h-\alpha-$ syn $_{\mathrm{A} 53 \mathrm{~T}}$ at calyces (Fig. 1D). Coimmunostaining of $\mathrm{vGluT}_{1}$ and $\mathrm{h}-\alpha-\mathrm{syn}_{\mathrm{A} 53 \mathrm{~T}}$ confirmed the presence of $\mathrm{h}-\alpha-\mathrm{syn}_{\mathrm{A} 53 \mathrm{~T}}$ in $94 \%$ of vGluT $\mathrm{T}_{1}$-containing calyces (220 of 234 calyces, two mice) in h- $\alpha$-syn A53T_calyx $_{\text {mice, }}$ but not in control mice (three Math ${ }^{\mathrm{Cre}}$ mice; Fig. $\left.1 E, F\right)$. The $\mathrm{h}-\alpha$-syn ${ }_{\mathrm{A53T}}$ expression level in calyces increased slightly from P5 to P18 (Fig. 1E,F), which is consistent with the finding that Math5 promoter is turned on as early as embryonic day 12.5 , and 
A

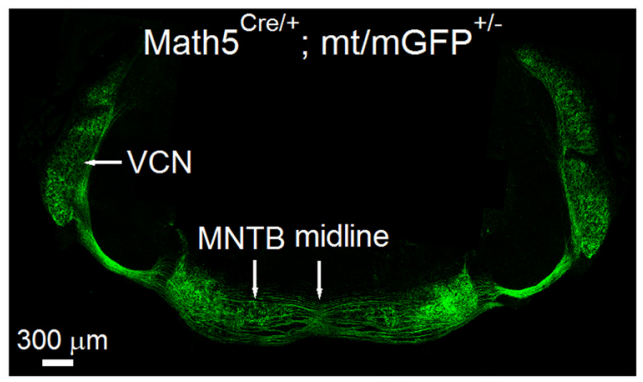

C

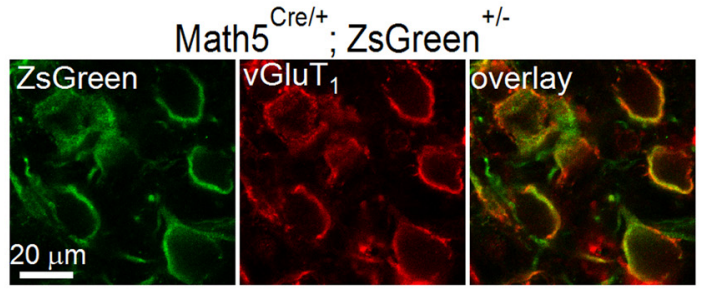

$\mathbf{E}$

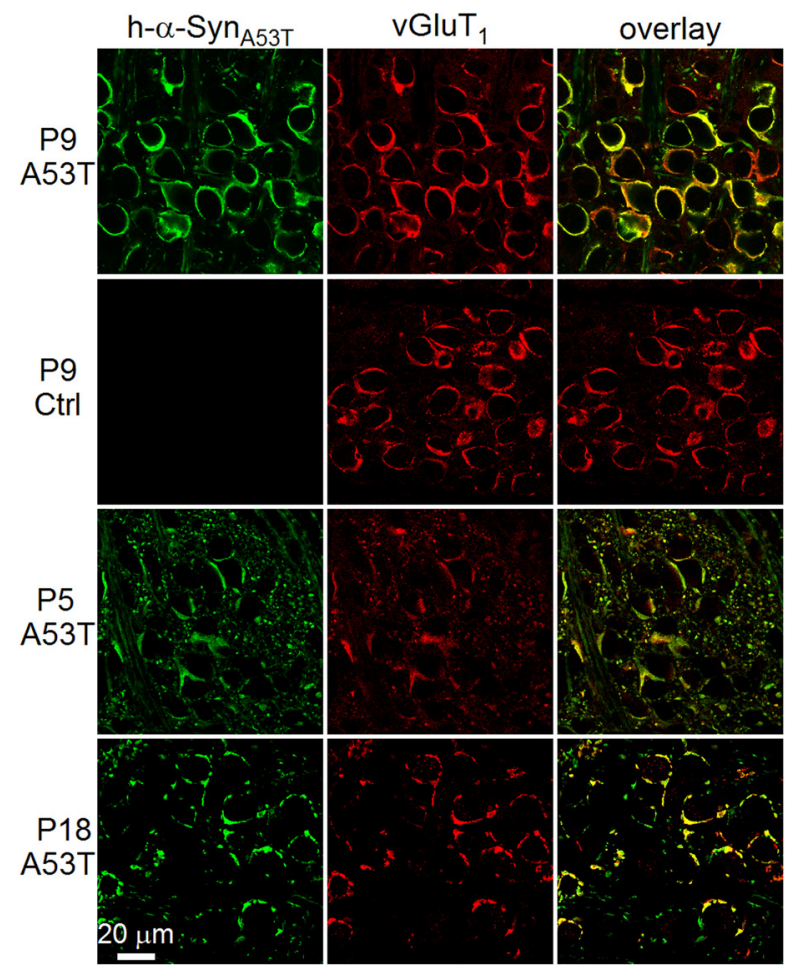

H

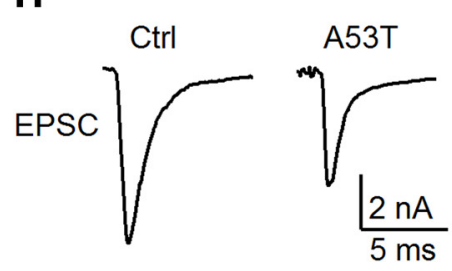

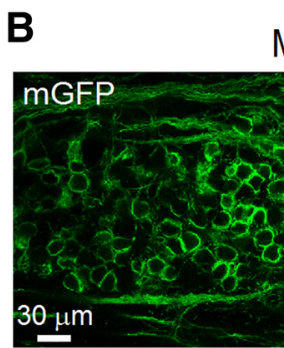

Math $5^{\mathrm{Cre} /+} ; \mathrm{mt} / \mathrm{mGFP}^{+/-}$
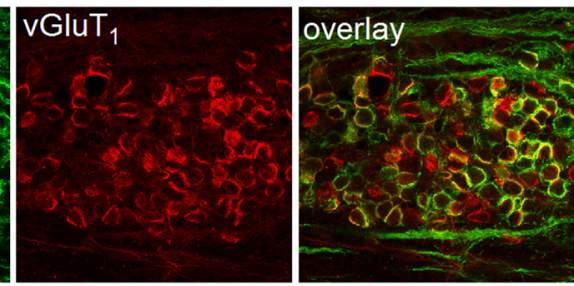

D Mouse breeding

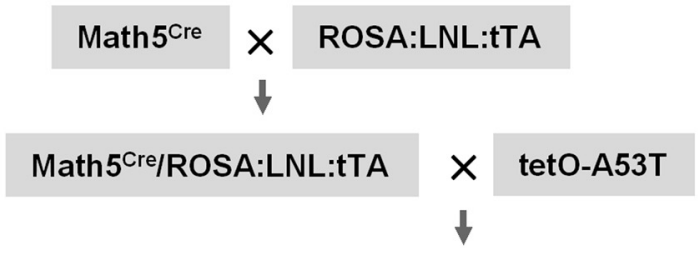

Math5Cre/tetO-A53T/ROSA:LNL:tTA

$\mathbf{F}$
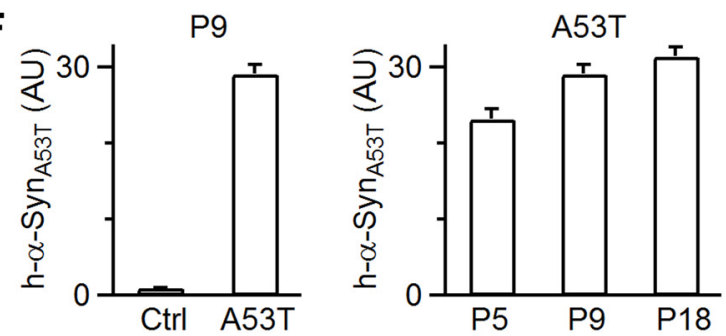

G Math5 ${ }^{\mathrm{Cre} /+} /$ tetO-A53T/ROSA:LNL:tTA
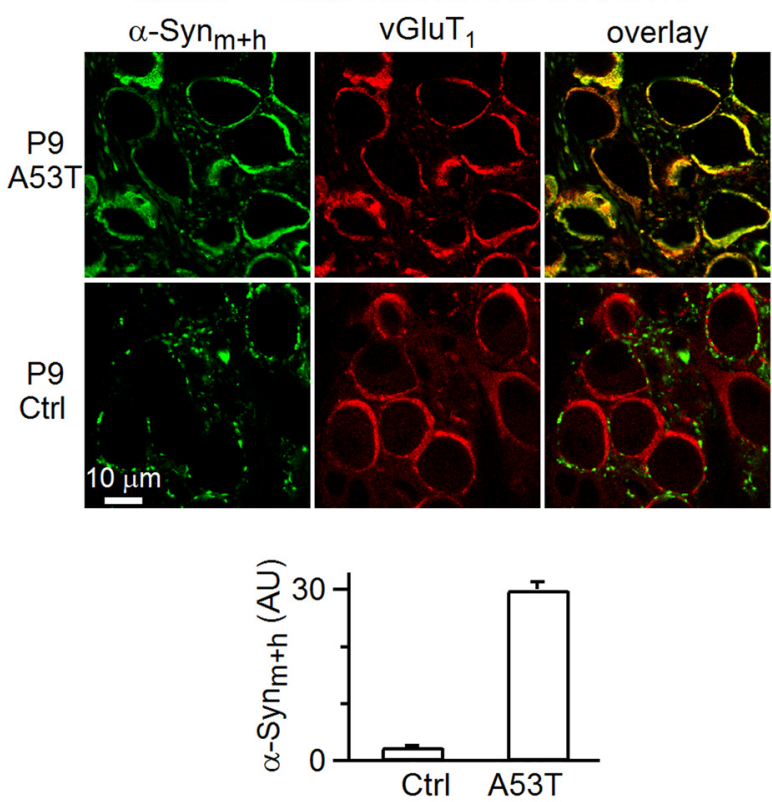

Figure 1. Identification of a Cre mouse line specific for calyces and overexpression of $\mathrm{h}-\alpha$-syn $\mathrm{A}_{\mathrm{A53}}$ in calyces. $\boldsymbol{A}$, Horizontal brainstem section showing limited expression of Math $5^{\text {cre }}$ in the auditory system. Math $5^{\text {Cre }}$ expression was detected with antibody staining of GFP in Math $5^{\mathrm{Cre} /+} ; \mathrm{mT} / \mathrm{mGFP}^{+/-}$mice. VCN, Ventral cochlear nucleus, containing globular bushy cells giving rise to calyces; MNTB, medial nucleus of the trapezoid body, containing calyces. B, Immunostaining in MNTB: Math5 ${ }^{\text {Cre }}$ expression (green: GFP antibody staining, left) overlaps with most vGluT ${ }_{1}$ antibody staining (red, pseudocolor, middle) that labels calyces in Math5 ${ }^{\text {Cre/ }+} ; \mathrm{mT} / \mathrm{mGFP}^{+/-}$mice (left and middle panel superimposed in the right). $C_{\text {, Math }}{ }^{\text {(re }}$ (Figure legend continues.) 
remains active postnatally in young and adult calyx-containing neurons (Saul et al., 2008). Immunostaining with an antibody recognizing both mouse $\alpha$-syn and h- $\alpha$-syn ${ }_{\mathrm{A} 53 \mathrm{~T}}$ showed that at $\mathrm{P} 7-\mathrm{P} 10$ the staining intensity at calyces in $\mathrm{h}-\alpha-\operatorname{syn}_{\mathrm{A} 53 \mathrm{~T} \text { calyx }}$ mice was $\sim 12$ times ( $n=129$ calyces, 3 mice) that of Math ${ }^{\text {Cre }}$ mice ( $n=83$ calyces, 3 mice; Fig. $1 G$ ), which is within the range (2.530 -fold increase) of overexpression level in various $\alpha$-syn transgenic mouse models (Fernagut and Chesselet, 2004).

An axonal fiber stimulus, which induced a presynaptic action potential (Xu and $\mathrm{Wu}, 2005)$, evoked a mean EPSC of $7.2 \pm 0.5 \mathrm{nA}$ in P7-P10 control mice ( $n=7$ calyces, 7 mice), but a reduced EPSC of $4.6 \pm 0.9 \mathrm{nA}$ in $\mathrm{p} 7-10 \mathrm{~h}-\alpha-$ syn $_{\text {A53T_calyx }}$ mice $(n=7$ calyces, 7 mice; $p=0.02$, Fig. $1 H$ ). This result is consistent with a previous finding that $\alpha$-syn mutations suppress transmitter release (Nemani et al., 2010; Lundblad et al., 2012; Janezic et al., 2013).

Next, we examined how h- $\alpha$-syn ${ }_{\mathrm{A} 53 \mathrm{~T}}$ overexpression affects presynaptic mechanisms at P7-P10 calyces, at which neurodegeneration is too early to develop (Petrucci et al., 2016). In control mice, including Math5 ${ }^{\mathrm{Cre}}$ and wild-type mice, a $20 \mathrm{~ms}$ depolarization from -80 to $+10 \mathrm{mV}$ ( depol $_{20 \mathrm{~ms}}$ ) induced a calcium current (ICa; $1.7 \pm 0.1 \mathrm{nA})$ and exocytosis $\left(\Delta C_{m} ; 379 \pm 14\right.$ fF, $n=22$ calyces, 8 mice; Fig. $2 A)$. $C_{m}$ decayed monoexponentially with a $\tau$ of $\sim 10-25 \mathrm{~s}$ and a Rate decay $_{\text {of }} 26.8 \pm 2.1 \mathrm{fF} / \mathrm{s}(n=$ 22 calyces, 8 mice; Fig. $2 A$ ), which reflect slow endocytosis (Wu et al., 2009). In h- $\alpha$-syn ${ }_{\text {A53T_calyx }}$ mice, depol ${ }_{20 m s}$ induced an ICa and a $\Delta C_{m}$ similar to control (Fig. $2 B, C$ ), but a significantly smaller Rate $_{\text {decay }}(17 \pm 2 \mathrm{fF} / \mathrm{s}, n=26$ calyces, 9 mice, $p<0.01$; Fig. $2 B, C)$, suggesting that h- $\alpha$-syn ${ }_{\mathrm{A} 53 \mathrm{~T}}$ inhibits slow endocytosis.

To study rapid endocytosis, we applied $10 \operatorname{depol}_{20 \mathrm{~ms}}$ at $10 \mathrm{~Hz}$ $\left(\right.$ depol $\left._{20 \mathrm{~ms} \times 10}\right)$ to induce rapid endocytosis. In control mice, depol $_{20 \mathrm{~ms} \times 10}$ induced a $\Delta C_{m}$ of $1160 \pm 71 \mathrm{fF}$, which decayed biexponentially with a rapid and a slow $\tau$ of $1-3.5$ and 10-30 s, respectively (31 calyces, 11 mice; Fig. $3 A$ ). The Rate decay was $163 \pm 16 \mathrm{fF} / \mathrm{s}(n=31$ calyces, 11 mice; Fig. $3 A)$, which reflected mostly $(>80 \%)$ the rapid component of endocytosis (Wu et al., 2005, 2009; Sun et al., 2010). In $\mathrm{h}-\alpha-\operatorname{syn}_{\mathrm{A} 53 \mathrm{~T}+c a l y x}$ mice, depol $_{20 \mathrm{~ms} \times 10}$ induced a $\Delta C_{m}(898 \pm 68 \mathrm{fF}, n=30$ calyces, 10 mice) and a Rate decay $(78 \pm 9 \mathrm{fF} / \mathrm{s}, n=30$ calyces $)$ that were both significantly smaller than control $(p<0.01$; Fig. $3 A-C)$, suggesting that $\mathrm{h}-\alpha-\operatorname{syn}_{\mathrm{A} 53 \mathrm{~T}}$ inhibited rapid endocytosis. The decrease in $\Delta C_{m}$ after $\operatorname{depol}_{20 \mathrm{~ms} \times 10}$, but not after $\operatorname{depol}_{20 \mathrm{~ms}}$, reflected a reduced replenishment of the RRP, because depol $_{20 \mathrm{~ms}}$ depletes the

(Figure legend continued.) expression, detected from antibody staining of ZsGreen (green, left), overlaps with most vGluT 1 staining (red, labeling calyces, middle) in MNTB of Math $5^{\text {(re/+/, }}$ $\mathrm{ZsGreen}^{+l-}$ mouse (left and middle panel superimposed in the right). D, Breeding scheme for the generation of a Math $5^{\mathrm{Cre}} /$ tet0-A53T/ROSA:LNL:tTA ( $\mathrm{h}-\alpha$ - -Syn $_{\text {A53T_calyx }}$ ) triple-transgenic mouse. $E$, $\mathrm{h}-\alpha$-syn A53T $_{\text {(green, left) and vGluT }}$ staining (red, labeling calyces, middle) in MNTB

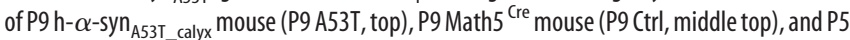
(middle bottom) and P18 (bottom) $\mathrm{h}-\alpha$-syn ${ }_{\text {A53T_calyx }}$ mouse (green and red images are also superimposed in the right). $F$, Left, Immunostaining intensity (arbitrary unit, AU; mean + SEM)

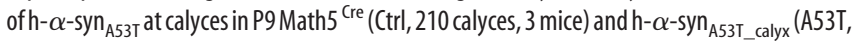
164 calyces, 3 mice) mice. Right, Immunostaining intensity of $\mathrm{h}-\alpha$-syn ${ }_{\mathrm{A53T}}$ at calyces in P5 (74 calyces, 3 mice), P9 (164 calyces, 3 mice), and P18 (228 calyces, 3 mice) h- $\alpha$-syn A53T_calyx $_{\text {mice. }}$ G, Top, Sampled immunostaining with an antibody recognizing both mouse $\alpha$-syn and $\mathrm{h}-\alpha$ syn $_{\text {A53T }}$ (green, $\alpha$-syn ${ }_{m+h}$ ) and vGluT 1 staining (red) in P9 $\mathrm{h}-\alpha$ - Syn $_{\text {A53T_calyx }}$ mouse (A53T, top) and Math5 ${ }^{\text {Cre }}$ mouse (Ctrl, bottom). Bottom, $\alpha$-syn ${ }_{\mathrm{m}+\mathrm{h}}$ immunostaining intensity (in AU) in P9 Math5 ${ }^{\text {Cre }}$ mouse (Ctrl, 83 calyces, 3 mice) and h- $\alpha$-syn ${ }_{\text {A53T calyx }}$ mouse (A53T, 129 calyces, 3 mice). $\boldsymbol{H}$, Sampled EPSCS (left) and the amplitude of EPSCS (right, mean \pm SEM) induced by a presynaptic fiber stimulation in $\mathrm{h}-\alpha$-Syn $\mathrm{A}_{\mathrm{A} 3 \mathrm{~T} \text { _calyx }}$ mice (A53T, 7 mice, 7 neurons) and Ctrl mice (including Math $5^{\text {Cre }}$ and wild-type mice, 7 mice, 7 neurons). ${ }^{*} p<0.05$.
A

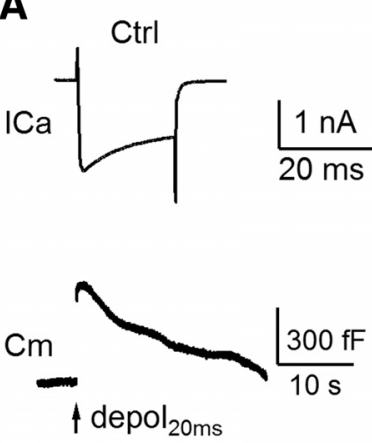

B
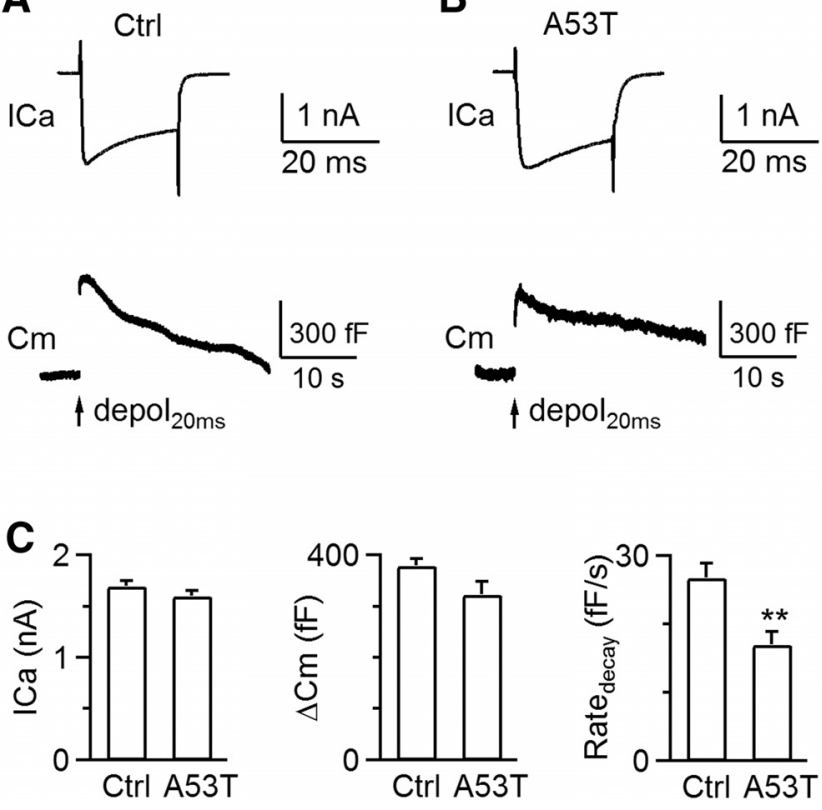

Figure 2. Inhibition of slow endocytosis at calyces in $\mathrm{h}-\alpha-\mathrm{Syn}_{\mathrm{A} 3 \mathrm{~T} \text { _calyx }}$ mice. $\boldsymbol{A}, \boldsymbol{B}$, Sampled ICa (top) and capacitance changes $\left(C_{m}\right.$, bottom) induced by depol ${ }_{20 m s}$ (arrow) in control (Ctrl, $\left.\boldsymbol{A}\right)$

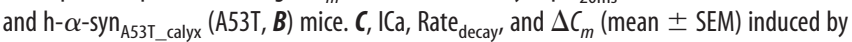
depol $_{20 \mathrm{~ms}}$ in Ctrl (22 calyces, 8 mice) and A53T mice ( 26 calyces, 9 mice). ${ }^{* *} p<0.01$.
A

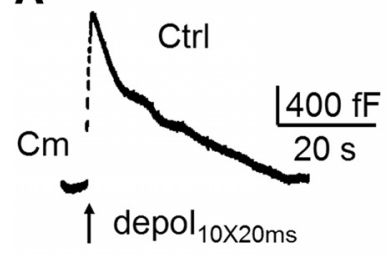

C

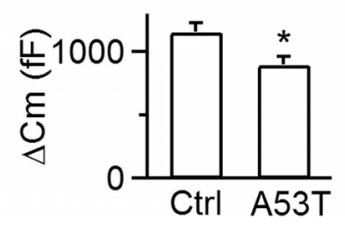

B
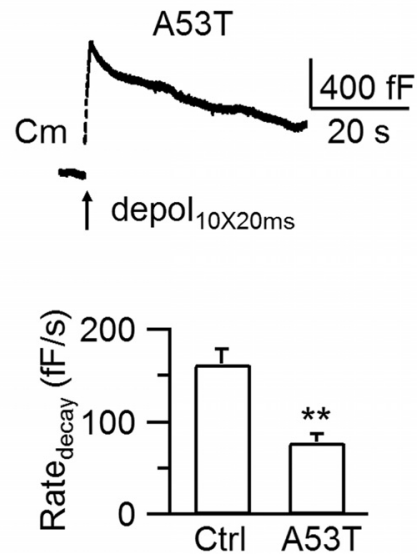

Figure 3. Inhibition of rapid endocytosis at calyces in h- $\alpha-$ syn $_{\mathrm{A} 53 \mathrm{~T}}$ calyx mice. $\boldsymbol{A}, \boldsymbol{B}$, Sampled capacitance changes $\left(C_{m}\right.$, bottom) induced by depol ${ }_{20 \mathrm{~ms} \times 10}$ (arrow) in control $(\boldsymbol{A})$ and h- $\alpha-$ syn $_{\text {A53T_calyx }}(\boldsymbol{B})$ mice. $\boldsymbol{C}$, Rate decay $_{\text {and }} \Delta C_{m}$ (mean \pm SEM) induced by depol $_{20 \mathrm{~ms} \times 10}$ in Ctrl (31 calyces, 11 mice) and A53T mice (30 calyces, 10 mice). ${ }^{*} p<0.05$; ${ }^{* *} p<0.01$.

RRP, whereas depol ${ }_{20 \mathrm{~ms} \times 10}$ causes repeated RRP depletion and replenishment (Wu et al., 2009).

Inhibition of rapid and slow endocytosis in h- $\alpha$-syn ${ }_{\mathrm{A} 53 \mathrm{~T} \_ \text {calyx }}$ mice was not due to $\Delta C_{m}$ reduction, because the decrease of Rate $_{\text {decay }}$ after depol ${ }_{20 \mathrm{~ms}}$ was not accompanied by a significant $\Delta C_{m}$ decrease (Fig. 2). The $\Delta C_{m}$ induced by depol $_{20 \mathrm{~ms} \times 10}$ decreased by only $\sim 23 \%$, which was insufficient to account for an $\sim 52 \%$ reduction in Rate decay (Fig. 3 ). Furthermore, exocytosis reduction has not been shown to prolong endocytosis time course or to reduce Rate $_{\text {decay }}$ (Wu et al., 2005, 2009, 2014; Renden and von Gersdorff, 2007).

In $\mathrm{h}-\alpha-\operatorname{syn}_{\mathrm{A} 53 \mathrm{~T} \_ \text {calyx }}$ mice, the $\mathrm{h}-\alpha$ - $\mathrm{syn}_{\mathrm{A} 53 \mathrm{~T}}$ level was elevated for days. In the following, we determined whether short-term 
A

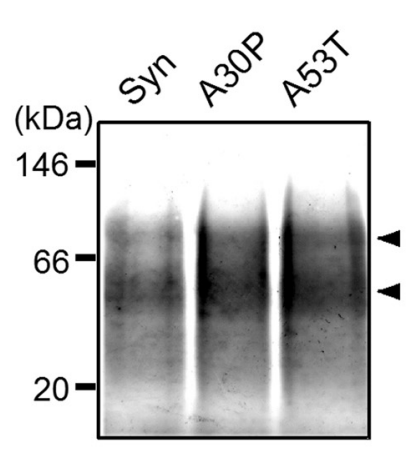

B Rat: dialysis
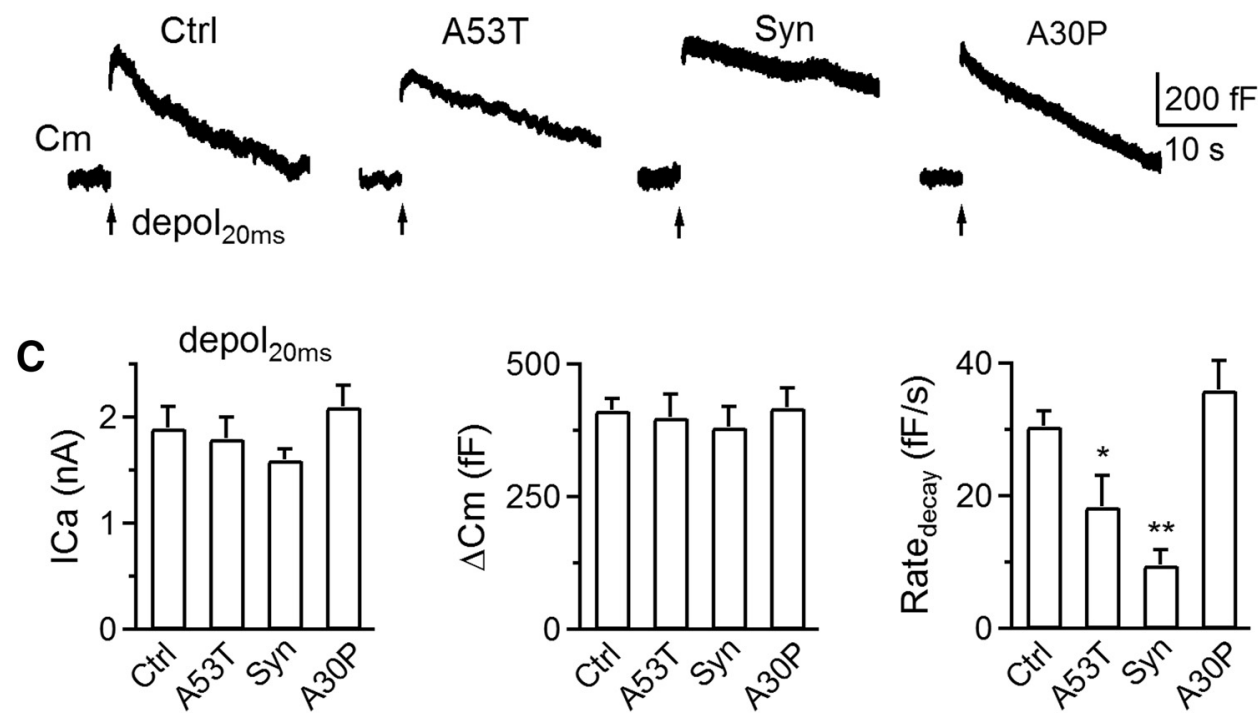

\section{Rat: dialysis}
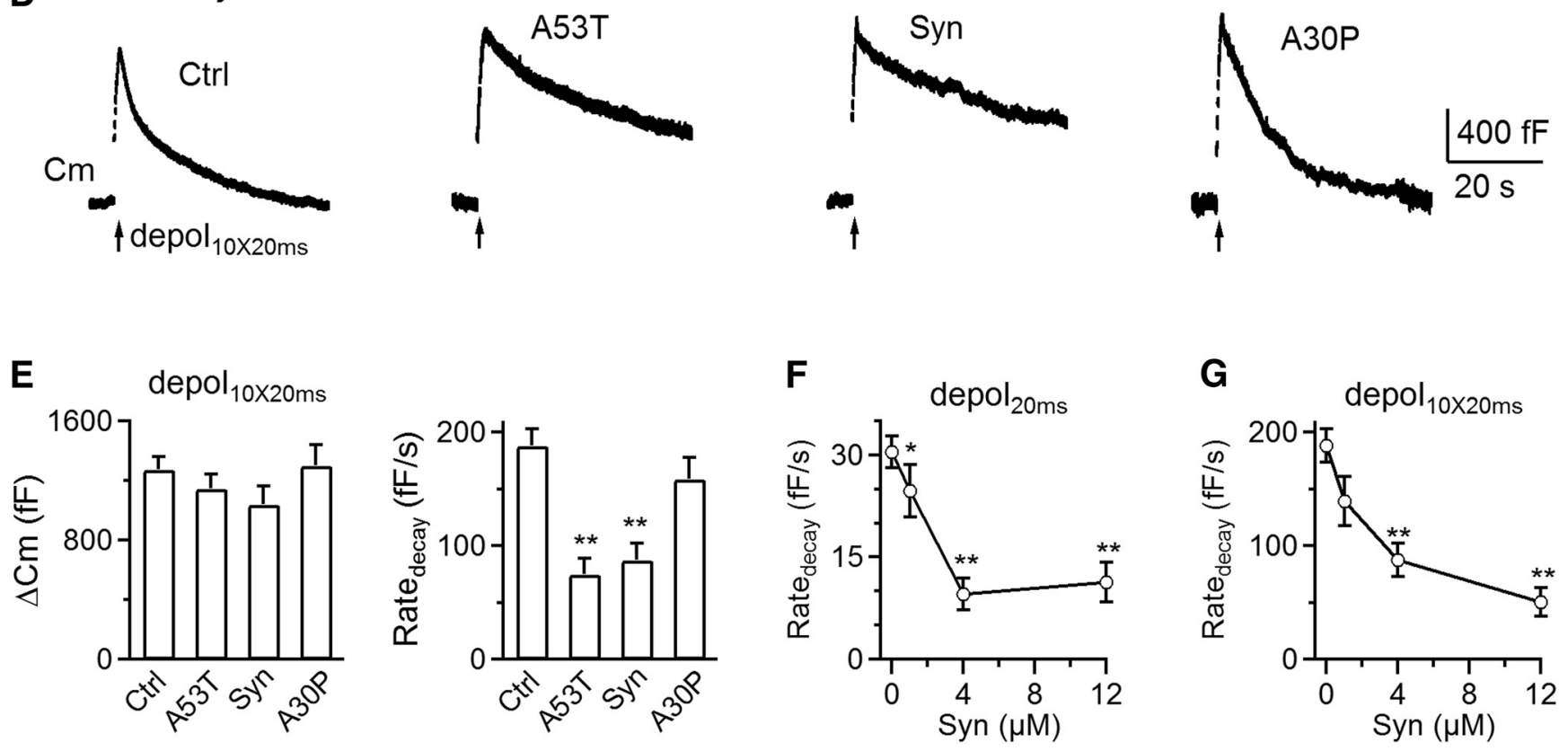

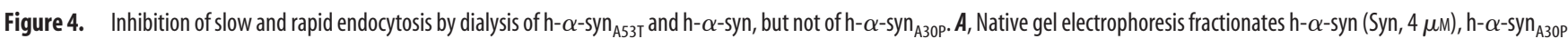

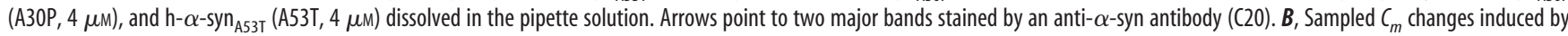

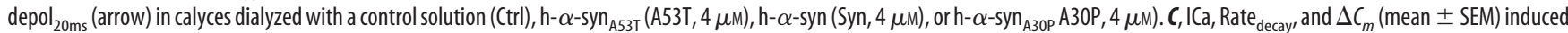

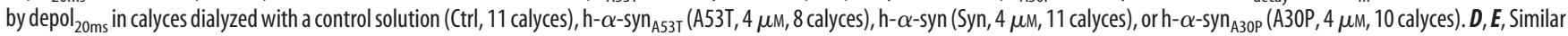

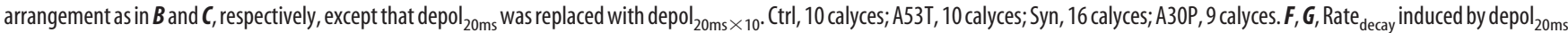
$(\boldsymbol{F})$ and depol ${ }_{20 \mathrm{~ms} \times 10}(\boldsymbol{G})$ in rat calyces dialyzed with $\mathrm{h}$ - $\alpha$-syn at $0 \mu \mathrm{m}$ (11 calyces in $\boldsymbol{F}, 10$ calyces in $\left.\boldsymbol{G}\right), 1 \mu \mathrm{m}$ ( 9 calyces in $\boldsymbol{F}, 8$ calyces in $\left.\boldsymbol{G}\right), 4 \mu \mathrm{m}(11$ calyces in $\boldsymbol{F}$, 16 calyces in $\boldsymbol{G})$, and $12 \mu \mathrm{m}(8$ calyces in $\boldsymbol{F}, 9$ calyces in $\boldsymbol{G}$ ).

whole-cell dialysis of h- $\alpha$-syn ${ }_{\mathrm{A} 53 \mathrm{~T}}$, wild-type $\mathrm{h}-\alpha$-syn, and $\mathrm{h}-\alpha$ $\operatorname{syn}_{\mathrm{A} 30 \mathrm{P}}$ inhibits endocytosis in P7-P10 rat calyces. The concentration we used was $4 \mu \mathrm{M}$, because endogenous $\alpha$-syn is $\sim 2-5 \mu \mathrm{M}$ (Westphal and Chandra, 2013). Native gel electrophoresis showed two major bands of $\sim 50$ and $\sim 100 \mathrm{kDa}$ for these three proteins dissolved in the pipette solution (Fig. 4A), suggesting that $\alpha$-syn (monomer, $\sim 14 \mathrm{kDa}$ ) proteins are most likely tetramers and octamers, consistent with $\alpha$-syn tetramers found in physiological conditions (Bartels et al., 2011).
At 5-10 min after whole-cell break-in, $\mathrm{h}-\alpha$-syn ${ }_{\mathrm{A} 53 \mathrm{~T}}$ dialysis decreased Rate decay $_{\text {induced by depol }}$ ioms from $31 \pm 2 \mathrm{fF} / \mathrm{s}(n=$ $11)$ in control to $18.4 \pm 4 \mathrm{fF} / \mathrm{s}(n=8, p<0.05)$ without significantly affecting ICa or $\Delta C_{m}$ (Fig. $4 B, C$ ). h- $\alpha$ - syn $_{\mathrm{A} 53 \mathrm{~T}}$ dialysis also

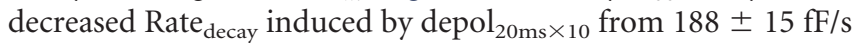
$(n=10)$ in control to $75 \pm 14 \mathrm{fF} / \mathrm{s}$ ( $n=10$ calyces, $p<0.01$; Fig. $4 D, E)$. Similar reduction was observed at calyces dialyzed by

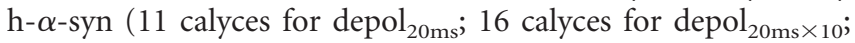
$p<0.01)$, but not by h- $\alpha-\operatorname{syn}_{\mathrm{A} 30 \mathrm{P}}(4 \mu \mathrm{M}, n=10$ and 9 calyces, 
respectively; Fig. $4 B-E$ ). The effect of h- $\alpha$-syn on Rate decay $_{\text {in- }}$ duced by depol ${ }_{20 \mathrm{~ms}}$ and depol $_{20 \mathrm{~ms} \times 10}$ was dose dependent, and approached saturation at $\sim 4 \mu \mathrm{M}$ (Fig. $4 F-G$ ). Thus, like chronically expressed $\mathrm{h}-\alpha-\mathrm{syn}_{\mathrm{A} 53 \mathrm{~T}}$, short-term dialysis of $\mathrm{h}-\alpha-\mathrm{syn}_{\mathrm{A} 53 \mathrm{~T}}$ and h- $\alpha$-syn inhibited both slow and rapid endocytosis, while the dialysis of $\mathrm{h}-\alpha-\operatorname{syn}_{\mathrm{A} 30 \mathrm{P}}$ did not. Unlike long-term $\mathrm{h}-\alpha-\mathrm{syn}_{\mathrm{A} 53 \mathrm{~T}}$ expression, h- $\alpha$-syn ${ }_{\mathrm{A53T}}$ dialysis did not affect $\Delta C_{m}$ induced by $\operatorname{depol}_{20 \mathrm{~ms} \times 10}$ (Fig. 4B-E), probably due to shorter exposure.

\section{Discussion}

We reported for the first time that a prolonged increase of h- $\alpha$ $\operatorname{syn}_{\mathrm{A} 53 \mathrm{~T}}$ impairs synaptic transmission at a mammalian nerve terminal, the calyx of Held, by inhibiting both slow and rapid endocytosis, and the RRP replenishment (Figs. 2, 3). Short-term dialysis of h- $\alpha$-syn ${ }_{\mathrm{A} 53 \mathrm{~T}}$ or h- $\alpha$-syn into calyces similarly inhibited slow and rapid endocytosis (Fig. 4). These defects may contribute to the synaptic impairment observed before the overt neurodegeneration in $\alpha$-syn-linked neurodegenerative disorders, such as PD, dementia with Lewy bodies, and multiple-systems atrophy. They might be a sign of early neurodegeneration.

Inhibition of RRP replenishment by prolonged elevation of the levels of $\mathrm{h}-\alpha-\operatorname{syn}_{\mathrm{A} 53 \mathrm{~T}}$ in $\mathrm{h}-\alpha-\mathrm{syn}_{\mathrm{A53} \text { _calyx }}$ mice could result from long-term inhibition of endocytosis, because endocytosis recycles vesicle membrane as well as facilitates the RRP replenishment by clearance of the active zone (for review, see Wu et al., 2014). However, we could not exclude the possibility that the prolonged elevation of h- $\alpha$-syn $\mathrm{A53T}_{\mathrm{T}}$ levels inhibits RRP replenishment by a mechanism independent of endocytosis.

A recent study (Busch et al., 2014) shows that short-term injection of h- $\alpha-\operatorname{syn}_{\mathrm{A} 53 \mathrm{~T}}$ into lamprey nerve terminals leads to expansion of the plasma membrane and reduction of vesicle numbers, implying a defect in vesicle recycling. Our work advances over this previous study in three aspects. First, by realtime endocytosis measurements, we provided direct evidence for the inhibitory effects of $\mathrm{h}-\alpha-\mathrm{syn}_{\mathrm{A} 53 \mathrm{~T}}$ on the two most common forms of endocytosis, slow and rapid endocytosis. Second, we found that endocytosis was inhibited not only by acute elevation, but also by prolonged elevation of h- $\alpha-\operatorname{syn}_{\mathrm{A} 53 \mathrm{~T}}$ levels in $\mathrm{h}-\alpha-$ syn $_{\text {A53T_calyx }}$ mice that mimics the constant presence of $\alpha$-syn mutant proteins in $\alpha$-syn-linked neurodegeneration. Third, our observations were from mammalian central synapses.

$\alpha$-syn ${ }_{\mathrm{A53T}}$ and $\alpha$-syn, but not $\alpha$-syn $\operatorname{s30P}_{\mathrm{P}}$, reduce synaptic vesicle number and expand plasma membrane area at lamprey synapses (Busch et al., 2014), and inhibit transmitter release at cultured hippocampal synapses (Nemani et al., 2010). Consistently, we found that $\mathrm{h}-\alpha-\mathrm{syn}_{\mathrm{A} 53 \mathrm{~T}}$ and $\mathrm{h}-\alpha$-syn, but not h- $\alpha$ $\operatorname{syn}_{\mathrm{A30P}}$, inhibited endocytosis. The lack of inhibitory effects of $\alpha$-syn $_{\mathrm{A} 30 \mathrm{P}}$ might be due to its weaker membrane binding affinity than $\alpha$-syn or $\alpha$-syn A53T $_{\text {T }}$ (Jo et al., 2002; Outeiro and Lindquist, 2003; Bussell and Eliezer, 2003). We could not exclude the possibility that the longer exposure of $\alpha-\operatorname{syn}_{\mathrm{A} 30 \mathrm{P}}$ in older mice inhibits endocytosis and exocytosis, considering that the $\alpha$-syn $\mathrm{A30P}_{\mathrm{P}} \mathrm{mu}-$ tation is associated with late $\mathrm{PD}$ onset and incomplete penetrance (Krüger et al., 2001).

$\alpha$-Syn participates in membrane curvature formation and sensing (Pranke et al., 2011; Westphal and Chandra, 2013). Ex-

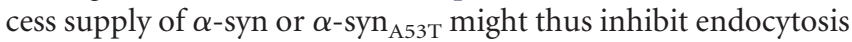
by affecting curvature formation. Since triple knockout of $\alpha$-syn, $\beta$-syn, and $\gamma$-syn also inhibits endocytosis at hippocampal synapses (Vargas et al., 2014), we suggest that the right balance of the amount of synuclein in nerve terminals is critical for endocytosis.

Several possible mechanisms might explain how elevated levels of $\alpha$-syn ${ }_{\mathrm{A} 53 \mathrm{~T}}$ or $\alpha$-syn inhibits endocytosis. $\alpha$-Syn can interact with SNARE (Chandra et al., 2005; Burré et al., 2010; Darios et al., 2010) and cysteine string protein (Miller et al., 2003), which are known to regulate endocytosis (Deák et al., 2004; Hosoi et al., 2009; Rozas et al., 2012; Zhang et al., 2012, 2013; Xu et al., 2013). Alternatively, $\alpha$-syn can bind to neuronal membrane and form nonselective cation pores (Mironov, 2015), permitting calcium influx to elevate intracellular calcium levels. If the increased calcium level is global, prolonged, and small, it may slow down endocytosis (von Gersdorff and Matthews, 1994; Wu and Wu, 2014) and thus explain why elevated an $\alpha$-syn level inhibits endocytosis. Identifying the mechanism by which $\mathrm{h}-\alpha-\operatorname{syn}_{\mathrm{A} 53 \mathrm{~T}}$ and $\mathrm{h}-\alpha$-syn inhibit endocytosis will be an interesting future research direction.

In addition to the study of endocytosis, the present work provided the first mouse line, the Math $5^{\mathrm{Cre}}$ mouse, for generating gene knockout or expression specifically in calyces but not in postsynaptic neurons (Fig. 1). The calyx is a preparation of choice for examining biophysical properties of nerve terminals, such as calcium channels, calcium affinity to exocytosis, exocytosis and endocytosis modes, and short-term synaptic plasticity (Borst and Soria van Hoeve, 2012). However, molecular studies of these processes at calyces have been limited partly because global gene knockout is often lethal at birth, before calyces are formed. This problem can now be overcome by making conditional knockout using the Math $5{ }^{\mathrm{Cr}}$ mouse line. The combination of this mouse line with various disease mouse models will open the door to study presynaptic mechanisms of neurological disorders.

\section{References}

Bartels T, Choi JG, Selkoe DJ (2011) alpha-Synuclein occurs physiologically as a helically folded tetramer that resists aggregation. Nature 477: 107-110. CrossRef Medline

Bendor JT, Logan TP, Edwards RH (2013) The function of alpha-synuclein. Neuron 79:1044-1066. CrossRef Medline

Borst JG, Soria van Hoeve J (2012) The calyx of held synapse: from model synapse to auditory relay. Annu Rev Physiol 74:199-224. CrossRef Medline

Burré J, Sharma M, Tsetsenis T, Buchman V, Etherton MR, Südhof TC (2010) Alpha-synuclein promotes SNARE-complex assembly in vivo and in vitro. Science 329:1663-1667. CrossRef Medline

Busch DJ, Oliphint PA, Walsh RB, Banks SM, Woods WS, George JM, Morgan JR (2014) Acute increase of alpha-synuclein inhibits synaptic vesicle recycling evoked during intense stimulation. Mol Biol Cell 25:3926-3941. CrossRef Medline

Bussell R Jr, Eliezer D (2003) A structural and functional role for 11-mer repeats in alpha-synuclein and other exchangeable lipid binding proteins. J Mol Biol 329:763-778. CrossRef Medline

Chandra S, Gallardo G, Fernández-Chacón R, Schlüter OM, Südhof TC (2005) Alpha-synuclein cooperates with CSPalpha in preventing neurodegeneration. Cell 123:383-396. CrossRef Medline

Darios F, Ruipérez V, López I, Villanueva J, Gutierrez LM, Davletov B (2010) Alpha-synuclein sequesters arachidonic acid to modulate SNAREmediated exocytosis. EMBO Rep 11:528-533. CrossRef Medline

Deák F, Schoch S, Liu X, Südhof TC, Kavalali ET (2004) Synaptobrevin is essential for fast synaptic-vesicle endocytosis. Nat Cell Biol 6:1102-1108. CrossRef Medline

Fernagut PO, Chesselet MF (2004) Alpha-synuclein and transgenic mouse models. Neurobiol Dis 17:123-130. CrossRef Medline

Hosoi N, Holt M, Sakaba T (2009) Calcium dependence of exo- and endocytotic coupling at a glutamatergic synapse. Neuron 63:216-229. CrossRef Medline

Janezic S, Threlfell S, Dodson PD, Dowie MJ, Taylor TN, Potgieter D, Parkkinen L, Senior SL, Anwar S, Ryan B, Deltheil T, Kosillo P, Cioroch M, Wagner K, Ansorge O, Bannerman DM, Bolam JP, Magill PJ, Cragg SJ, Wade-Martins R (2013) Deficits in dopaminergic transmission precede neuron loss and dysfunction in a new Parkinson model. Proc Natl Acad Sci U S A 110:E4016-E4025. CrossRef Medline

Jo E, Fuller N, Rand RP, St George-Hyslop P, Fraser PE (2002) Defective 
membrane interactions of familial Parkinson's disease mutant A30P alpha-synuclein. J Mol Biol 315:799-807. CrossRef Medline

Krüger R, Kuhn W, Leenders KL, Sprengelmeyer R, Müller T, Woitalla D, Portman AT, Maguire RP, Veenma L, Schröder U, Schöls L, Epplen JT, Riess O, Przuntek H (2001) Familial parkinsonism with synuclein pathology: clinical and PET studies of A30P mutation carriers. Neurology 56:1355-1362. CrossRef Medline

Kurz A, Double KL, Lastres-Becker I, Tozzi A, Tantucci M, Bockhart V, Bonin M, García-Arencibia M, Nuber S, Schlaudraff F, Liss B, Fernández-Ruiz J, Gerlach M, Wüllner U, Lüddens H, Calabresi P, Auburger G, Gispert S (2010) A53T-alpha-synuclein overexpression impairs dopamine signaling and striatal synaptic plasticity in old mice. PLoS One 5:e11464. CrossRef Medline

Larsen KE, Schmitz Y, Troyer MD, Mosharov E, Dietrich P, Quazi AZ, Savalle M, Nemani V, Chaudhry FA, Edwards RH, Stefanis L, Sulzer D (2006) $\alpha$-Synuclein overexpression in PC12 and chromaffin cells impairs catecholamine release by interfering with a late step in exocytosis. J Neurosci 26:11915-11922. CrossRef Medline

Lin X, Parisiadou L, Sgobio C, Liu G, Yu J, Sun L, Shim H, Gu XL, Luo J, Long CX, Ding J, Mateo Y, Sullivan PH, Wu LG, Goldstein DS, Lovinger D, Cai H (2012) Conditional expression of Parkinson's disease-related mutant alpha-synuclein in the midbrain dopaminergic neurons causes progressive neurodegeneration and degradation of transcription factor nuclear receptor related 1. J Neurosci 32:9248-9264. CrossRef Medline

Lundblad M, Decressac M, Mattsson B, Björklund A (2012) Impaired neurotransmission caused by overexpression of alpha-synuclein in nigral dopamine neurons. Proc Natl Acad Sci U S A 109:3213-3219. CrossRef Medline

Miller LC, Swayne LA, Kay JG, Feng ZP, Jarvis SE, Zamponi GW, Braun JE (2003) Molecular determinants of cysteine string protein modulation of N-type calcium channels. J Cell Sci 116:2967-2974. CrossRef Medline

Mironov SL (2015) alpha-Synuclein forms non-selective cation channels and stimulates ATP-sensitive potassium channels in hippocampal neurons. J Physiol 593:145-159. CrossRef Medline

Muzumdar MD, Tasic B, Miyamichi K, Li L, Luo L (2007) A global doublefluorescent Cre reporter mouse. Genesis 45:593-605. CrossRef Medline

Nemani VM, Lu W, Berge V, Nakamura K, Onoa B, Lee MK, Chaudhry FA, Nicoll RA, Edwards RH (2010) Increased expression of alpha-synuclein reduces neurotransmitter release by inhibiting synaptic vesicle reclustering after endocytosis. Neuron 65:66-79. CrossRef Medline

Outeiro TF, Lindquist S (2003) Yeast cells provide insight into alphasynuclein biology and pathobiology. Science 302:1772-1775. CrossRef Medline

Petrucci S, Ginevrino M, Valente EM (2016) Phenotypic spectrum of alphasynuclein mutations: new insights from patients and cellular models. Parkinsonism Relat Disord 22 [Suppl 1]:S16-S20. CrossRef Medline

Polymeropoulos MH, Lavedan C, Leroy E, Ide SE, Dehejia A, Dutra A, Pike B, Root H, Rubenstein J, Boyer R, Stenroos ES, Chandrasekharappa S, Athanassiadou A, Papapetropoulos T, Johnson WG, Lazzarini AM, Duvoisin RC, Di Iorio G, Golbe LI, Nussbaum RL (1997) Mutation in the alphasynuclein gene identified in families with Parkinson's disease. Science 276:2045-2047. CrossRef Medline

Pranke IM, Morello V, Bigay J, Gibson K, Verbavatz JM, Antonny B, Jackson CL (2011) alpha-Synuclein and ALPS motifs are membrane curvature sensors whose contrasting chemistry mediates selective vesicle binding. J Cell Biol 194:89-103. CrossRef Medline

Renden R, von Gersdorff H (2007) Synaptic vesicle endocytosis at a CNS nerve terminal: faster kinetics at physiological temperatures and increased endocytotic capacity during maturation. J Neurophysiol 98:3349-3359. CrossRef Medline

Rozas JL, Gómez-Sánchez L, Mircheski J, Linares-Clemente P, NietoGonzález JL, Vázquez ME, Luján R, Fernández-Chacón R (2012) Motorneurons require cysteine string protein-alpha to maintain the readily releasable vesicular pool and synaptic vesicle recycling. Neuron 74: 151-165. CrossRef Medline

Saul SM, Brzezinski JA 4th, Altschuler RA, Shore SE, Rudolph DD, Kabara LL, Halsey KE, Hufnagel RB, Zhou J, Dolan DF, Glaser T (2008) Math5 expression and function in the central auditory system. Mol Cell Neurosci 37:153-169. CrossRef Medline

Scott DA, Tabarean I, Tang Y, Cartier A, Masliah E, Roy S (2010) A pathologic cascade leading to synaptic dysfunction in $\alpha$-synuclein-induced neurodegeneration. J Neurosci 30:8083-8095. CrossRef Medline

Sun T, Wu XS, Xu J, McNeil BD, Pang ZP, Yang W, Bai L, Qadri S, Molkentin JD, Yue DT, Wu LG (2010) The role of calcium/calmodulin-activated calcineurin in rapid and slow endocytosis at central synapses. J Neurosci 30:11838-11847. CrossRef Medline

Vargas KJ, Makani S, Davis T, Westphal CH, Castillo PE, Chandra SS (2014) Synucleins regulate the kinetics of synaptic vesicle endocytosis. J Neurosci 34:9364-9376. CrossRef Medline

von Gersdorff H, Matthews G (1994) Inhibition of endocytosis by elevated internal calcium in a synaptic terminal. Nature 370:652-655. CrossRef Medline

Wang L, Sharma K, Deng HX, Siddique T, Grisotti G, Liu E, Roos RP (2008) Restricted expression of mutant SOD1 in spinal motor neurons and interneurons induces motor neuron pathology. Neurobiol Dis 29:400-408. CrossRef Medline

Westphal CH, Chandra SS (2013) Monomeric synucleins generate membrane curvature. J Biol Chem 288:1829-1840. CrossRef Medline

Wu LG, Hamid E, Shin W, Chiang HC (2014) Exocytosis and endocytosis: modes, functions, and coupling mechanisms. Annu Rev Physiol 76: 301-331. CrossRef Medline

Wu W, Xu J, Wu XS, Wu LG (2005) Activity-dependent acceleration of endocytosis at a central synapse. J Neurosci 25:11676-11683. CrossRef Medline

Wu XS, Wu LG (2014) The yin and yang of calcium effects on synaptic vesicle endocytosis. J Neurosci 34:2652-2659. CrossRef Medline

Wu XS, McNeil BD, Xu J, Fan J, Xue L, Melicoff E, Adachi R, Bai L, Wu LG (2009) $\mathrm{Ca}(2+)$ and calmodulin initiate all forms of endocytosis during depolarization at a nerve terminal. Nat Neurosci 12:1003-1010. CrossRef Medline

$\mathrm{Xu} \mathrm{J,} \mathrm{Wu} \mathrm{LG} \mathrm{(2005)} \mathrm{The} \mathrm{decrease} \mathrm{in} \mathrm{the} \mathrm{presynaptic} \mathrm{calcium} \mathrm{current} \mathrm{is} \mathrm{a}$ major cause of short-term depression at a calyx-type synapse. Neuron 46:633-645. CrossRef Medline

Xu J, Luo F, Zhang Z, Xue L, Wu XS, Chiang HC, Shin W, Wu LG (2013) SNARE proteins synaptobrevin, SNAP-25, and syntaxin are involved in rapid and slow endocytosis at synapses. Cell Rep 3:1414-1421. CrossRef Medline

Yang Z, Ding K, Pan L, Deng M, Gan L (2003) Math5 determines the competence state of retinal ganglion cell progenitors. Dev Biol 264:240-254. CrossRef Medline

Zhang YQ, Henderson MX, Colangelo CM, Ginsberg SD, Bruce C, Wu T, Chandra SS (2012) Identification of CSPalpha clients reveals a role in dynamin 1 regulation. Neuron 74:136-150. CrossRef Medline

Zhang Z, Wang D, Sun T, Xu J, Chiang HC, Shin W, Wu LG (2013) The SNARE proteins SNAP25 and synaptobrevin are involved in endocytosis at hippocampal synapses. J Neurosci 33:9169-9175. CrossRef Medline 